\section{Metabolites of the phenylpropanoid pathway and physiological quality of soybean seeds in storage}

\author{
Julia Abati ${ }^{1 *}\left(\mathbb{D}\right.$, , Claudemir Zucareli ${ }^{1}(\mathbb{D})$, Cristian Rafael Brzezinski ${ }^{2}$ (D) Francisco \\ Carlos Krzyzanowski ${ }^{3} \mathbb{D}$, José de Barros França-Neto ${ }^{3} \mathbb{D}^{D}$, Fernando Augusto \\ Henning ${ }^{3}$
}

ABSTRACT: The aim of this study was to evaluate changes in the physiological quality of soybean seeds throughout a storage period in two environments, and to evaluate how these changes are related to metabolites of the phenylpropanoid pathway. A completely randomized experimental design was used in a $4 \times 8$ factorial arrangement (storage periods $\times$ cultivars) with four replications. We used seeds from cultivars with contrasts in lignin content, color, and presence of anthocyanin in the seed coat, and isoflavone content in the seed. The seeds were kept for six months under cold and dry storage and in a noncontrolled environment. Germination, first germination count, seedling emergence, and tetrazolium testing were performed on the seeds every two months. The physiological quality of the seeds declines during the storage period, with higher rates of decrease in the non-controlled environment. The metabolites of the phenylpropanoid pathway that were studied, especially lignin, affect seed storage potential. Cultivars with higher lignin content show greater storage potential, especially in a non-controlled environment.

Index terms: deterioration, Glycine $\max$ (L.) Merrill, isoflavone, lignin, seed coat color.

RESUMO: O objetivo do trabalho foi avaliar as alterações na qualidade fisiológica de sementes de soja ao longo do período de armazenamento em dois ambientes e sua relação com metabólitos da rota dos fenilpropanóides. O delineamento experimental foi inteiramente casualizado, em esquema fatorial $4 \times 8$ (períodos de armazenamento $x$ cultivares), com quatro repetições. Foram utilizadas sementes de cultivares com características contrastantes de teor de lignina, cor e presença de antocianina no tegumento e teor de isoflavona na semente, armazenadas durante seis meses em câmara fria e seca e em ambiente não controlado. Periodicamente, a cada dois meses, as sementes foram avaliadas quanto à germinação, primeira contagem de germinação, emergência de plântulas e tetrazólio. A qualidade fisiológica das sementes é reduzida ao longo do armazenamento, com maiores taxas de decréscimo no ambiente não controlado. Os metabólitos da rota dos fenilpropanóides estudados, especialmente a lignina, interferem no potencial de armazenamento das sementes. Cultivares com maiores teores de lignina apresentam maior potencial de armazenamento, principalmente em ambiente não controlado.

Termos para indexação: deterioração, Glycine max (L.) Merrill, isoflavona, lignina, cor do tegumento.
Journal of Seed Science, v.43, e202143033, 2021

http://dx.doi.org/10.1590/ 2317-1545v43253585
*Corresponding author.
E-mail: juliaabati@yahoo.com.br

Received: 06/24/2021.

Accepted: 08/17/2021.

${ }^{1}$ Departamento de Agronomia, Universidade Estadual de Londrina, Caixa Postal 6001, 86057-970 Londrina, PR, Brasil.

${ }^{2}$ Departamento de Pesquisa, GDM Genética do Brasil S.A., 77500-000, Porto Nacional, TO, Brasil.

${ }^{3}$ Embrapa Soja, Caixa Postal 231, 86001-970, Londrina, PR, Brasil. 


\section{INTRODUCTION}

Brazil is a reference in technology for soybean seed production; yet improvements in the production system are still necessary. Prominent challenges are to increase the production and use of high-quality seeds and to select and develop cultivars with a view toward seed quality in plant breeding programs and the potential of preserving this quality during storage (Carvalho et al., 2014; França-Neto et al., 2016; 2020).

Several factors can affect seed quality and seed conservation during storage. The deterioration process during the storage period cannot be prevented; however, depending on the management practices during storage and on the seed characteristics, the intensity and speed of this process can be reduced (Cardoso et al., 2012; Vidigal et al., 2016). Therefore, some growers are investing in climate control of seed storage areas through control of relative humidity (RH) and temperature reduction.

Furthermore, soybean seed materials have differing longevities, which causes apprehension in the seed sector and is a challenge for breeding programs. In this respect, Carvalho et al. (2014), Rosa et al. (2017), and Schons et al. (2018) found that soybean cultivars have different levels of tolerance to deterioration during the storage period.

Thus, it is necessary to identify and understand characteristics related to seed quality and seed longevity. Studies directed to the phenylpropanoid pathway are notable, since this is the biosynthetic pathway for formation of diverse compounds present in seeds, including lignin, anthocyanin, and isoflavone (Liu et al., 2015).

Capeleti et al. (2005), Huth et al. (2016), and Marwanto and Marlinda (2003) found that soybean seeds with greater lignin content in the seed coat have greater resistance to mechanical damage, greater resistance to weathering deterioration prior to harvest, and greater storage potential, respectively.

Mertz et al. (2009) and Bahry et al. (2017) found that seeds with a black seed coat (that have anthocyanin accumulation in the seed coat) have greater physiological quality than those with a yellow seed coat. Furthermore, Bahry et al. (2015) found that soybean seeds with a black seed coat have a greater concentration of phenolic compounds and antioxidant potential than those with a yellow seed coat.

Another compound present in soybean seeds is isoflavones, though studies regarding the effect they have on seed quality and longevity are still quite limited. Nevertheless, it is known that isoflavones have important biological functions, such as antioxidant activity. This can minimize the effects of deterioration, due to greater protection of seed cells from the action of free radicals (Ávila et al., 2012), which may confer greater storage potential.

Therefore, some metabolites of the phenylpropanoid pathway are conditioning factors of seed quality. However, exploratory studies are necessary aiming to relate them to seed storage potential. Thus, the aim of the present study was to evaluate the changes in physiological quality of seeds from different soybean cultivars throughout the storage period in two environments and to evaluate how these changes are related to metabolites of the phenylpropanoid pathway.

\section{MATERIAL AND METHODS}

The experiment was developed at the National Soybean Research Center of the Brazilian Agricultural Research Corporation (Embrapa Soybean) in Londrina, Paraná, Brazil. We used seeds from soybean cultivars with contrasts in lignin content, color, and presence of anthocyanin in the seed coat, and isoflavone content in the seeds (Table 1).

Lignin content in the seed coat, used to characterize cultivars together with seed coat color (presence of anthocyanin) and isoflavone content, was determined using four replications of 100 seeds for each treatment, which were initially immersed in water for 12 hours. Then the seed coats were removed and dried in a laboratory oven at $105{ }^{\circ} \mathrm{C}$ for 24 hours. The dry matter obtained was ground and homogenized. After that, 300-mg samples of the ground seed coat were separated and centrifuged with different solutions (sodium and potassium phosphate, Triton X-100, 1.0 $\mathrm{M} \mathrm{NaCl}$, deionized water, and acetone) to obtain the cell wall. The samples were then placed in a vacuum dryer and subsequently in a laboratory oven at $60^{\circ} \mathrm{C}$. After the samples were dried, they were macerated, and the material free 
Table 1. Characterization of cultivars regarding metabolites of the phenylpropanoid pathway (color, anthocyanin, and lignin content in the seed coat; and isoflavone content in seeds).

\begin{tabular}{ccccc}
\hline & \multicolumn{3}{c}{ Seed coat } & Seed \\
\cline { 2 - 5 } Cultivar & Color & Anthocyanin & $\begin{array}{c}\text { Lignin content } \\
(\%)\end{array}$ & $\begin{array}{c}\text { Isoflavone content } \\
\left(\begin{array}{l}\text { (mg.100 g of flour } \\
\text {-1 })\end{array}\right.\end{array}$ \\
\hline BRSMG 715A- L1* & Black & + & $14.07 \mathrm{~b}$ & $312.10 \mathrm{~b}$ \\
BRSMG 715A- L2* & Black & + & $14.38 \mathrm{a}$ & $332.78 \mathrm{a}$ \\
BRS 1001 IPRO & Yellow & - & $3.99 \mathrm{e}$ & $222.09 \mathrm{~d}$ \\
BRS 1003 IPRO & Yellow & - & $3.80 \mathrm{f}$ & $237.69 \mathrm{c}$ \\
BRS 413 RR & Yellow & - & $4.19 \mathrm{~d}$ & $233.74 \mathrm{c}$ \\
BRS 284 & Yellow & - & $4.25 \mathrm{~d}$ & $218.34 \mathrm{~d}$ \\
BMX Valente RR & Yellow & - & $3.29 \mathrm{~g}$ & $173.89 \mathrm{e}$ \\
DM 6563 IPRO & Yellow & - & $4.43 \mathrm{c}$ & $301.37 \mathrm{~b}$ \\
\hline
\end{tabular}

*L1 and L2: Lot 1 and Lot 2, respectively;

Mean values followed by the same letter in the column do not differ from each other by the Scott-Knott test at $5 \%$ probability;

Coefficient of variation - lignin content: $1.71 \%$ and isoflavone content: $3.46 \%$.

of proteins was obtained. The lignin was then quantified by the acetyl bromide method (Moreira-Vilar et al., 2014). The results were expressed in percentage.

Isoflavone content was determined according to the method of Carrão-Panizzi et al. (2002) in which seeds were ground and defatted with hexane under constant shaking for 16 hours. Then the samples were vacuum filtered. The material retained in the filter was kept at ambient temperature for four hours for evaporation of residual hexane. After that, $100 \mathrm{mg}$ of each ground and defatted sample was transferred to a $10 \mathrm{~mL}$ test tube. Next, $4 \mathrm{~mL}$ of $70 \%$ ethanol solution containing $0.1 \%$ acetic acid was added. The tubes containing the samples and the extraction solution were homogenized every fifteen minutes for one hour in a "vortex" type shaker. They were subjected to ultrasound for 30 minutes, and then the supernatant (1.5 mL of the extract) was transferred to Eppendorf tubes. The Eppendorf tubes were centrifuged for fifteen minutes at $14000 \mathrm{rpm}$ at $4{ }^{\circ} \mathrm{C}$. The supernatant was filtered through a membrane with $0.45 \mu \mathrm{m}$ pores, and $20 \mu \mathrm{L}$ of the filtered extract was used for injection in Ultra Performance Liquid Chromatography (UPLC). The isoflavones were quantified according to modifications in the methodology proposed by Berhow (2002) in a liquid chromatograph equipped with a reversed phase column, ACQUITY UPLC BEH C18, $1.7 \mu \mathrm{m}, 50 \times 2.1 \mathrm{~mm}$ diameter, and sample autoinjector. Results were expressed in $\mathrm{mg} .100 \mathrm{~g}^{-1}$ of flour.

To analyze the effects of storage, the seeds were placed in paper bag and kept for six months in two environments: cold and dry storage (under controlled temperature and $\mathrm{RH}$ conditions: $11{ }^{\circ} \mathrm{C}$ and $54 \% \mathrm{RH}$ ) and a non-controlled environment (under natural conditions). During the experiment, the temperature and $\mathrm{RH}$ of the two environments were monitored with the Data Logger model HT-500 device.

Evaluations were made in four storage periods: zero (initial characterization), two, four, and six months, so as to determine the changes in physiological quality of the seeds by means of the following tests.

Germination test: performed with two 50-seed subsamples per replication, for a total of 400 seeds per treatment. The seeds were distributed on germitest (germination testing) paper, moistened with distilled water in the amount of 2.5 times the weight of the substrate, and placed in a seed germinator at a temperature of $25{ }^{\circ} \mathrm{C}$. Evaluations were made after eight days, according to Brasil (2009), and the results were expressed in percentage.

First germination count: performed together with the germination test. Evaluation was made five days after setting up the test, with results expressed in percentage (Brasil, 2009).

Seedling emergence in sand: performed with 400 seeds per treatment, divided into four replications of 100 seeds. The seeds were sown in plastic trays $(0.45 \times 0.30 \times 0.10 \mathrm{~m})$ containing sand, under greenhouse conditions. The number 
of normal emerged seedlings was evaluated on the twelfth day, and results were expressed in percentage.

Tetrazolium test: conducted with 50 seeds per replication, pre-conditioned on germitest paper moistened with distilled water for a period of 16 hours in a seed germinator at a constant temperature of $25^{\circ} \mathrm{C}$. After that period, the seeds were transferred to plastic cups, totally submerged in tetrazolium solution (2,3,5-triphenyl-tetrazolium chloride) at a concentration of $0.075 \%$ and kept at the temperature of $40{ }^{\circ} \mathrm{C}$ for approximately 150 and 240 minutes for seeds with yellow and black seed coats, respectively. After that, the seeds were classified according to the criteria [viability, vigor, and weathering, stink bug, and mechanical damages (classes 6-8)] proposed by França-Neto and Krzyzanowski (2018). Results were expressed in percentage.

Acompletely randomized experimental design was used in a $4 \times 8$ (storage periods $\times$ cultivars) factorial arrangement, with four replications. The data were analyzed separately for each environment. The data on weathering damage, stink bug damage, and mechanical damage determined by the tetrazolium test were transformed into the square root of $(x+0.5)$. Analysis of variance was conducted at $5 \%$ probability. The means of the cultivars were compared by the Scott-Knott test, and analysis of regression was performed for the storage periods. Analyses were carried out by the Analysis of Variance System ("Sistema para Análise de Variância" - SISVAR) computational program (Ferreira, 2011). In the period of 0 and 6 months of storage, the Pearson correlation coefficients $(r)$ were calculated for the physiological quality variables analyzed in relation to the lignin and isoflavone content at $5 \%$ probability using the $R$ software (R Development Core Team, 2018).

\section{RESULTS AND DISCUSSION}

There was significant interaction between the storage periods and cultivars in the cold and dry storage environment and in the non-controlled environment for the following variables: viability, vigor, and weathering damage (classes 6-8), evaluated by the tetrazolium test. Furthermore, only in cold and dry storage was there interaction between the factors studied for stink bug damage (classes 6-8) and in the non-controlled environment for germination, first germination count, and seedling emergence. There was an isolated effect of cultivar and isolated effect of the storage period for germination, first germination count, and seedling emergence in cold and dry storage, and of mechanical damage (classes 6-8) in both storage environments. Furthermore, an isolated effect was found only for cultivar for stink bug damage (classes 6-8) in the non-controlled environment.

In the seeds under cold and dry storage, the cultivar 'BRSMG 715A' $L 2$ had the highest germination percentage, while the lowest values were of the cultivars 'BRS 1003 IPRO' and 'BRS 284', considering the mean of the four storage periods (Table 2). The germination percentage declined in a linear manner as the storage period increased, decreasing an average of five percentage points after six months of storage (Figure 1).

In storage in the non-controlled environment, interaction was found between the factors studied for the germination variable. In the cultivars evaluated, there was no difference in seed germination at 0 months (Table 3 ). This is an important result, since the initial quality of the seeds directly affects the intensity and speed of deterioration during storage. In the other storage periods, the cultivars responded differently and, at six months, the lowest values were found in 'BRS 1003 IPRO' and 'BRS 284', followed by 'BRS 1001 IPRO' (Table 3). In the non-controlled environment, it is noteworthy that after six months of storage, these cultivars had germination below the minimum standard necessary for commercialization of soybean seeds, which is $80 \%$, according to legislation (Brasil, 2013). In contrast, seed response in the cold and dry storage would allow all the cultivars to be commercialized.

During the storage period in the non-controlled environment, all the cultivars had linear reductions in the germination values. However, lower rates of decrease were found in 'BRSMG 715A' from L1 (Lot 1) and L2 (Lot 2) (Figure 2). This lower reduction may be related to the higher values of lignin and the presence of anthocyanin in the seed coat and isoflavones in the seeds of this cultivar (Table 1), which contributed to maintain the initial quality of the seeds during the storage period. This is confirmed by the correlation analysis described in this study (Table 5). 
Table 2. Germination (GER), first germination count (FGC), seedling emergence (SE), mechanical damage, classes 6-8 (MD6-8), and stink bug damage, classes 6-8 (SBD6-8), evaluated by the tetrazolium test, of soybean seeds according to cultivars; mean of four evaluations over the period of six months of storage under cold and dry storage conditions and in a non-controlled environment.

\begin{tabular}{ccccccc}
\hline \multirow{2}{*}{ Cultivar } & \multicolumn{3}{c}{ Cold and dry storage } & \multicolumn{2}{c}{ Non-controlled environment } \\
\cline { 2 - 7 } & GER (\%) & FGC (\%) & SE (\%) & MD6-8 (\%) & MD6-8 (\%) & SBD6-8 (\%) \\
\hline BRSMG 715A L1 & $90 \mathrm{c}$ & $86 \mathrm{~b}$ & $89 \mathrm{c}$ & $5 \mathrm{~b}$ & $6 \mathrm{a}$ & $1 \mathrm{a}$ \\
BRSMG 715A L2 & $95 \mathrm{a}$ & $91 \mathrm{a}$ & $95 \mathrm{a}$ & $3 \mathrm{a}$ & $4 \mathrm{a}$ & $3 \mathrm{~b}$ \\
BRS 1001 IPRO & $90 \mathrm{c}$ & $84 \mathrm{~b}$ & $89 \mathrm{c}$ & $10 \mathrm{~d}$ & $12 \mathrm{c}$ & $0 \mathrm{a}$ \\
BRS 1003 IPRO & $87 \mathrm{~d}$ & $78 \mathrm{c}$ & $90 \mathrm{c}$ & $5 \mathrm{~b}$ & $7 \mathrm{~b}$ & $0 \mathrm{a}$ \\
BRS 413 RR & $93 \mathrm{~b}$ & $85 \mathrm{~b}$ & $92 \mathrm{~b}$ & $6 \mathrm{~b}$ & $8 \mathrm{~b}$ & $1 \mathrm{a}$ \\
BRS 284 & $86 \mathrm{~d}$ & $74 \mathrm{c}$ & $87 \mathrm{~d}$ & $5 \mathrm{~b}$ & $5 \mathrm{a}$ & $5 \mathrm{c}$ \\
BMX Valente RR & $89 \mathrm{c}$ & $81 \mathrm{~b}$ & $90 \mathrm{c}$ & $9 \mathrm{c}$ & $8 \mathrm{~b}$ & $0 \mathrm{a}$ \\
DM 6563 IPRO & $89 \mathrm{c}$ & $76 \mathrm{c}$ & $91 \mathrm{c}$ & $11 \mathrm{~d}$ & $13 \mathrm{c}$ & $1 \mathrm{a}$ \\
\hline
\end{tabular}

Mean values followed by the same letter in the column do not differ from each other by the Scott-Knott test at $5 \%$ probability.
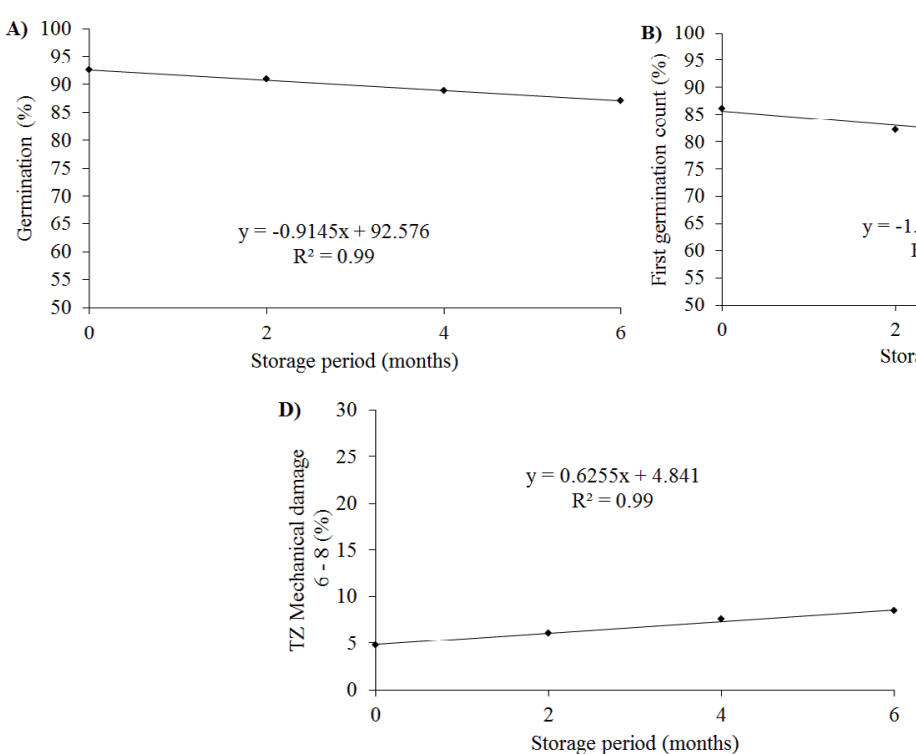
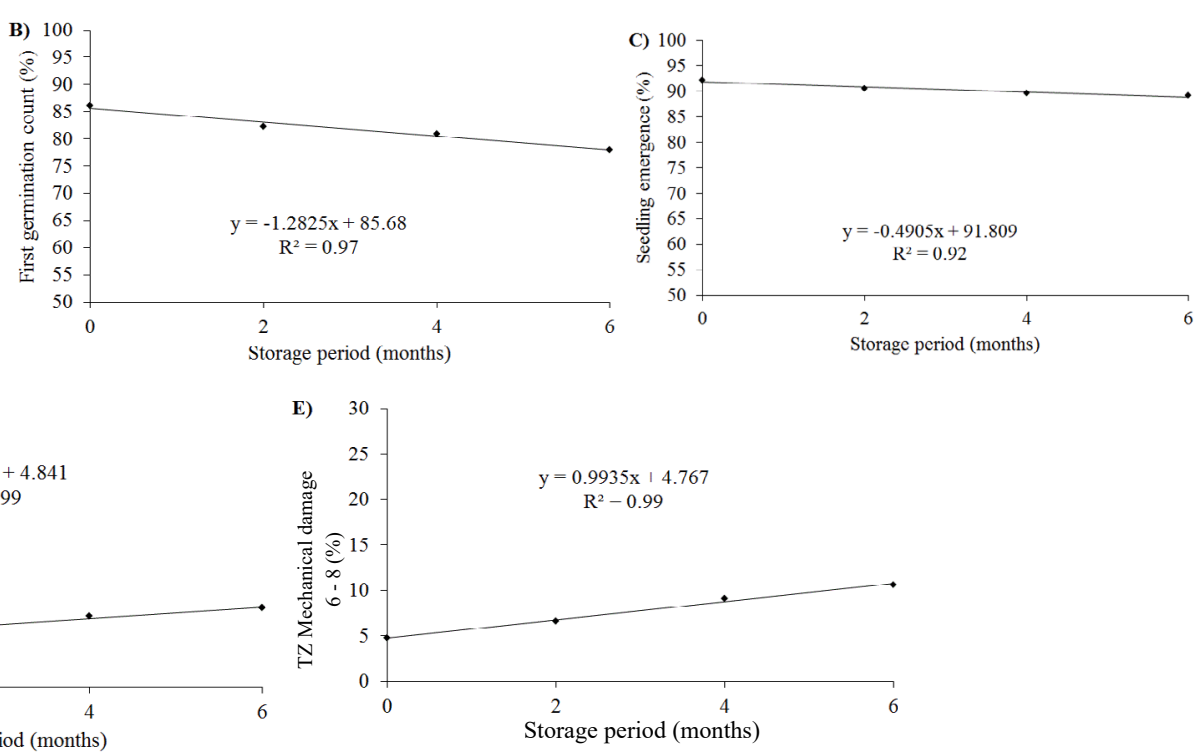

Figure 1. Germination, first germination count, seedling emergence, and mechanical damage (classes 6-8) by the tetrazolium test, according to storage periods under cold and dry storage (A, B, C, and D) and in a noncontrolled environment (E); mean of eight soybean cultivars.

Anthocyanin, accumulated in the seed coat of black soybean, and the isoflavones have antioxidant action (Ávila et al., 2012; Zabala and Vodkin, 2014; Choi et al., 2020). Antioxidants act in protecting cells, preventing the formation of free radicals or promoting sequestration or degradation of these molecules. Under unsuitable storage conditions, such as high temperatures and RH and pathogen attack, there is greater production of free radicals in seeds. Thus, the activation of antioxidant defense systems, whether enzymatic or non-enzymatic, is fundamental for preventing and/or retarding oxidative stress. 
Table 3. Germination (GER), first germination count (FGC), seedling emergence (SE), viability, vigor, and weathering damage (classes 6-8), evaluated by the tetrazolium test, of seeds of soybean cultivars during the storage period (SP) under non-controlled environmental conditions.

\begin{tabular}{|c|c|c|c|c|c|c|c|c|c|c|c|c|}
\hline \multirow{3}{*}{ Cultivar } & \multicolumn{4}{|c|}{ GER (\%) } & \multicolumn{4}{|c|}{ FGC (\%) } & \multicolumn{4}{|c|}{ SE (\%) } \\
\hline & \multicolumn{4}{|c|}{ SP (months) } & \multicolumn{4}{|c|}{ SP (months) } & \multicolumn{4}{|c|}{ SP (months) } \\
\hline & 0 & 2 & 4 & 6 & 0 & 2 & 4 & 6 & 0 & 2 & 4 & 6 \\
\hline BRSMG 715A L1 & $92 \mathrm{a}$ & $89 \mathrm{~b}$ & $88 a$ & $86 \mathrm{~b}$ & $91 \mathrm{a}$ & $85 a$ & $79 a$ & $75 a$ & $90 \mathrm{~b}$ & $92 \mathrm{~b}$ & $87 \mathrm{~b}$ & $85 \mathrm{~b}$ \\
\hline BRSMG 715A L2 & $95 \mathrm{a}$ & $95 a$ & $90 \mathrm{a}$ & $91 \mathrm{a}$ & $93 a$ & $92 \mathrm{a}$ & $85 a$ & $84 a$ & $98 \mathrm{a}$ & $96 a$ & $93 a$ & $91 \mathrm{a}$ \\
\hline BRS 1001 IPRO & $92 \mathrm{a}$ & $86 b$ & $83 \mathrm{~b}$ & $79 c$ & $87 a$ & $79 \mathrm{~b}$ & $79 a$ & $75 \mathrm{a}$ & $90 \mathrm{~b}$ & $85 c$ & $85 \mathrm{~b}$ & $83 \mathrm{~b}$ \\
\hline BRS 1003 IPRO & $91 \mathrm{a}$ & $89 \mathrm{~b}$ & $81 b$ & $75 d$ & $84 b$ & $84 a$ & $67 \mathrm{~b}$ & $60 \mathrm{~b}$ & $91 \mathrm{~b}$ & $88 c$ & $83 \mathrm{~b}$ & $77 c$ \\
\hline BRS 413 RR & 95 a & $90 \mathrm{~b}$ & $88 a$ & $85 b$ & $88 a$ & $84 a$ & $81 \mathrm{a}$ & $77 a$ & $94 \mathrm{a}$ & $93 \mathrm{~b}$ & $88 \mathrm{~b}$ & $87 a$ \\
\hline BRS 284 & $89 \mathrm{a}$ & $86 b$ & $81 b$ & $74 \mathrm{~d}$ & $78 \mathrm{~b}$ & $74 \mathrm{~b}$ & $73 b$ & $62 b$ & $88 \mathrm{~b}$ & $89 c$ & $79 c$ & $79 c$ \\
\hline BMX Valente RR & $95 \mathrm{a}$ & $92 \mathrm{a}$ & $85 a$ & $83 \mathrm{~b}$ & $90 \mathrm{a}$ & $86 a$ & $72 b$ & $63 \mathrm{~b}$ & $93 a$ & $88 c$ & $85 \mathrm{~b}$ & $83 \mathrm{~b}$ \\
\hline DM 6563 IPRO & $93 a$ & $90 \mathrm{~b}$ & $86 a$ & $82 \mathrm{~b}$ & $81 \mathrm{~b}$ & $80 \mathrm{~b}$ & $74 \mathrm{~b}$ & $65 b$ & $95 \mathrm{a}$ & $87 c$ & $86 \mathrm{~b}$ & $80 \mathrm{c}$ \\
\hline \multirow{2}{*}{ Cultivar } & \multicolumn{4}{|c|}{ TZ Viability (\%) } & \multicolumn{4}{|c|}{ TZ Vigor (\%) } & \multicolumn{4}{|c|}{ TZ Weathering 6-8 (\%) } \\
\hline & 0 & 2 & 4 & 6 & 0 & 2 & 4 & 6 & 0 & 2 & 4 & 6 \\
\hline BRSMG 715A L1 & $96 a$ & $95 a$ & $91 \mathrm{a}$ & $91 \mathrm{a}$ & $90 \mathrm{a}$ & $85 a$ & $83 a$ & $83 a$ & $0 \mathrm{a}$ & $0 \mathrm{a}$ & $1 \mathrm{a}$ & $0 \mathrm{a}$ \\
\hline BRSMG 715A L2 & $95 \mathrm{a}$ & $92 \mathrm{a}$ & $91 \mathrm{a}$ & $91 \mathrm{a}$ & $88 a$ & $84 a$ & $82 \mathrm{a}$ & $84 \mathrm{a}$ & $0 \mathrm{a}$ & $1 \mathrm{a}$ & $1 \mathrm{a}$ & $1 \mathrm{a}$ \\
\hline BRS 1001 IPRO & $90 \mathrm{~b}$ & $86 b$ & $84 b$ & $83 c$ & $84 b$ & $80 \mathrm{~b}$ & $78 \mathrm{~b}$ & $77 b$ & $1 \mathrm{a}$ & $2 a$ & $3 b$ & $4 \mathrm{~b}$ \\
\hline BRS 1003 IPRO & $92 b$ & $84 b$ & $84 b$ & $78 c$ & $86 b$ & $77 b$ & $75 c$ & $60 d$ & $4 \mathrm{~b}$ & $6 \mathrm{~b}$ & $9 d$ & $13 d$ \\
\hline BRS 413 RR & $94 \mathrm{a}$ & $92 a$ & $86 b$ & $86 b$ & $91 \mathrm{a}$ & $84 a$ & $80 a$ & $80 \mathrm{~b}$ & $1 \mathrm{a}$ & $3 a$ & $1 \mathrm{a}$ & $3 b$ \\
\hline BRS 284 & $90 \mathrm{~b}$ & $88 \mathrm{~b}$ & $81 \mathrm{~b}$ & $80 c$ & $80 \mathrm{~b}$ & $77 \mathrm{~b}$ & $72 c$ & $67 c$ & $1 \mathrm{a}$ & $3 a$ & $6 c$ & $8 c$ \\
\hline BMX Valente RR & $94 \mathrm{a}$ & $87 b$ & $85 b$ & $81 c$ & $90 \mathrm{a}$ & $85 a$ & $78 b$ & $68 c$ & $0 \mathrm{a}$ & $7 \mathrm{~b}$ & $6 c$ & $7 c$ \\
\hline DM 6563 IPRO & $91 \mathrm{~b}$ & $88 \mathrm{~b}$ & $83 \mathrm{~b}$ & $79 c$ & $85 \mathrm{~b}$ & $84 a$ & $77 \mathrm{~b}$ & $66 c$ & $0 \mathrm{a}$ & $2 a$ & $3 b$ & $2 b$ \\
\hline
\end{tabular}

Mean values followed by the same letter in the column do not differ from each other by the Scott-Knott test at $5 \%$ probability.

For first germination count, under cold and dry storage, 'BRSMG 715A' L2 exhibited the highest value (Table 2). For storage periods, the data referring to first germination count fit the linear equation, with an angular coefficient of -1.28. Thus, there was reduction in vigor as storage proceeded (Figure 1). In the non-controlled environment, 'BRSMG 715A' (L1 and L2), 'BRS 1001 IPRO', 'BRS 413 RR', and 'BMX Valente RR' showed greater speed of germination in the period prior to storage (0 months). The cultivars that showed the best results at two months were 'BRSMG 715A' (L1 and L2), 'BRS 1003 IPRO', 'BRS 413 RR', and 'BMX Valente RR'. At four and six months, the best results were for 'BRSMG 715A' (L1 and L2), 'BRS 1001 IPRO', and 'BRS 413 RR' (Table 3).

There is reduction in the speed of germination as the storage period proceeds for all the cultivars studied. Nevertheless, 'BRS 1003 IPRO' and 'BMX Valente RR', which have the lowest seed coat lignin values, showed the greatest rates of reduction in first germination count, with an angular coefficient of -4.45 and -4.68 , respectively (Figure 2), characterizing greater deterioration of these seeds.

Lignin is considered one of the factors that affect the quality and the deterioration of seeds (Bellaloui et al., 2017; Krzyzanowski and França-Neto, 2018). Corroborating this, Marwanto and Marlinda (2003) found that the lignin content in the seed coat had a negative correlation with membrane deterioration, associated with reduction in the quality of seeds after storage.

In cold and dry storage, the seeds of 'BRSMG 715A' L2 and 'BRS 284' resulted in the largest and smallest number of emerged seedlings, respectively (Table 2). In addition, a linear reduction was observed in the number of emerged 
seedlings during the storage period for all the cultivars (Figure 1). However, this reduction was low, considering the average of 2.9 percentage points after six months of storage.
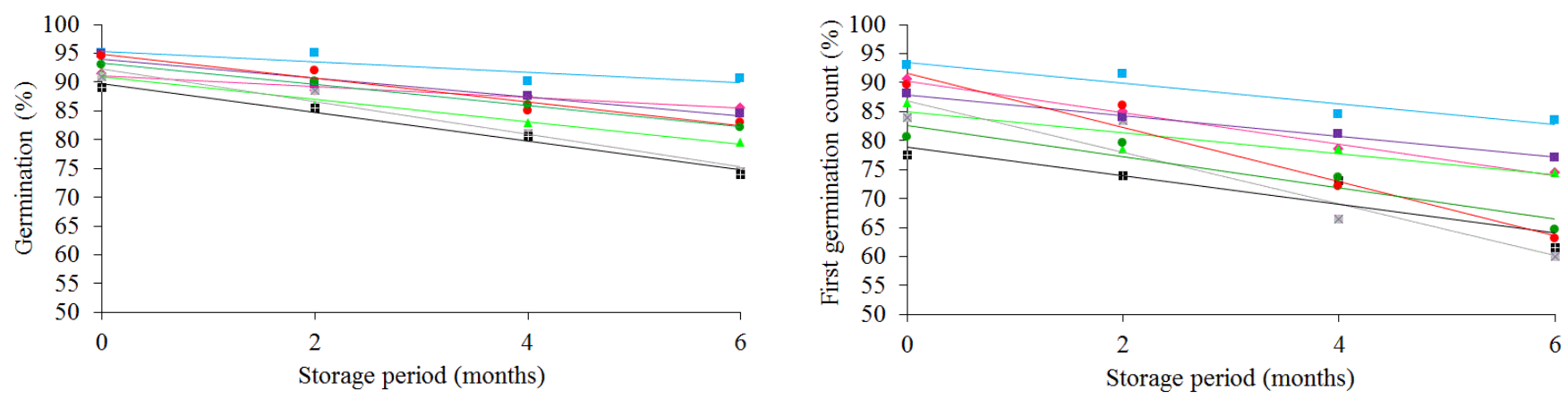

- $A: y=-0.95 x+91.1 R^{2}=0.96^{*} \quad=E: y=-1.6375 x+93.975 \quad R^{2}=0.96^{*}$

- $\mathrm{B}: \mathrm{y}=-0.925 \mathrm{x}+95.4 \mathrm{R}^{2}=0.75^{*} \quad$ \# $\mathrm{F}: \mathrm{y}=-2.5 \mathrm{x}+89.75 \mathrm{R}^{2}=0.98^{*}$

$\triangle \mathrm{C}: \mathrm{y}=-1.95 \mathrm{x}+90.85 \mathrm{R}^{2}=0.98^{*} \quad \bullet \mathrm{G}: \mathrm{y}=-2.075 \mathrm{x}+94.85 \mathrm{R}^{2}=0.95^{*}$

$₫ \mathrm{D}: \mathrm{y}=-2.85 \mathrm{x}+92.3 \mathrm{R}^{2}=0.97^{*} \quad \cdot \mathrm{H}: \mathrm{y}=-1.85 \mathrm{x}+93.3 \mathrm{R}^{2}=0.99^{*}$

- A: $y=-2.725 x+90.3 \quad R^{2}=0.99^{*} \quad$ - $E: y=-1.8 x+87.9 \quad R^{2}=0.99 *$ - $\mathrm{B}: \mathrm{y}=-1.775 \mathrm{x}+93.45 \mathrm{R}^{2}=0.90^{*} \quad$ \# $\mathrm{F}: \mathrm{y}=-2.45 \mathrm{x}+78.85 \mathrm{R}^{2}=0.83 *$ $\triangle \mathrm{C}: \mathrm{y}=-1.8 \mathrm{x}+84.9 \mathrm{R}^{2}=0.85^{*}$ × $\mathrm{D}: \mathrm{y}=-4.45 \mathrm{x}+86.85 \mathrm{R}^{2}=0.90 *$

- $\mathrm{G}: \mathrm{y}=-4.675 \mathrm{x}+91.65 \mathrm{R}^{2}=0.96^{*}$ - $\mathrm{H}: \mathrm{y}=-2.7 \mathrm{x}+82.6 \mathrm{R}^{2}=0.90^{*}$

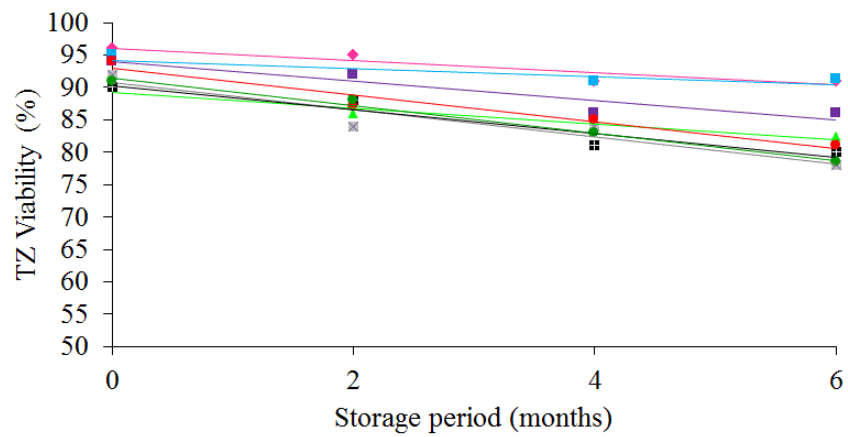

- A: $y=-0.95 x+96.1 \quad R^{2}=0.87^{*} \quad-\mathrm{E}: \mathrm{y}=-1.5 \mathrm{x}+94 \quad \mathrm{R}^{2}=0.88^{*}$ $*=\mathrm{B}: \mathrm{y}=-0.6125 \mathrm{x}+94.15 \mathrm{R}^{2}=0.74 * \quad=\mathrm{F}: \mathrm{y}=-1.85 \mathrm{x}+90.3 \mathrm{R}^{2}=0.92 *$ $\Delta \mathrm{C}: \mathrm{y}=-1.225 \mathrm{x}+89.3 \mathrm{R}^{2}=0.95^{*} \quad \bullet \mathrm{G}: \mathrm{y}=-2.05 \mathrm{x}+92.9 \mathrm{R}^{2}=0.95^{*}$ × $\mathrm{D}: \mathrm{y}=-2.1 \mathrm{x}+90.8 \quad \mathrm{R}^{2}=0.89^{*} \quad \bullet \mathrm{H}: \mathrm{y}=-2.125 \mathrm{x}+91.5 \mathrm{R}^{2}=0.99 *$

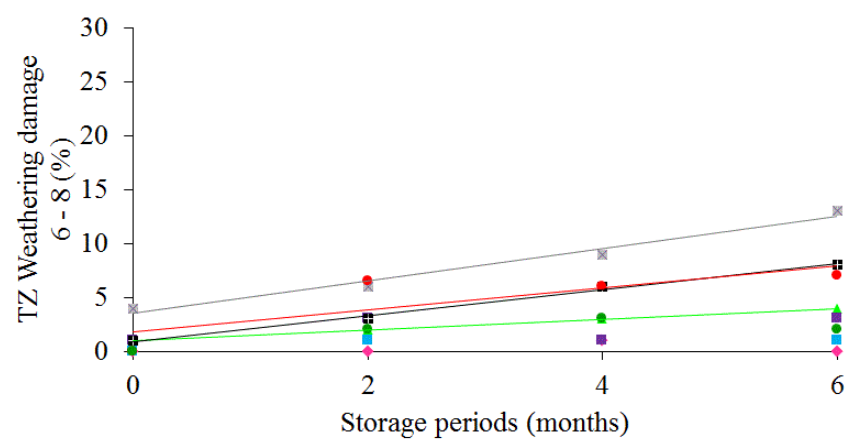

$$
\begin{aligned}
& \text { - } \mathrm{A} \text { : }{ }^{\mathrm{ns}} \quad-\mathrm{E} \text { : }{ }^{\mathrm{ns}} \\
& \text { - B: }{ }^{\text {ns }} \quad \text { * } \mathrm{F}: \mathrm{y}=1.2 \mathrm{x}+0.9 \quad \mathrm{R}^{2}=0.99 * \\
& \triangle \mathrm{C}: \mathrm{y}=0.5 \mathrm{x}+1 \quad \mathrm{R}^{2}=0.99 * \quad \bullet \mathrm{G}: \mathrm{y}=1.025 \mathrm{x}+1.8 \mathrm{R}^{2}=0.66^{*} \\
& \text { ॠ } \mathrm{D}: \mathrm{y}=1.5 \mathrm{x}+3.5 \quad \mathrm{R}^{2}=0.98^{*} \quad \bullet \mathrm{H} \text { : }{ }^{\text {ns }}
\end{aligned}
$$

${ }^{n s}$ and $*$ : non-significant and significant regression, respectively, at $5 \%$ probability;

Cultivars: A = BRSMG 715A L1; B = BRSMG 715A L2; C = BRS 1001 IPRO; D = BRS 1003 IPRO; E = BRS 413 RR; F = BRS 284; G = BMX Valente RR; $\mathrm{H}=\mathrm{DM} 6563$ IPRO.

Figure 2. Germination, first germination count, seedling emergence, viability, vigor, and weathering damage (classes 6-8), by the tetrazolium test, of seeds of soybean cultivars during the storage period under non-controlled environmental conditions. 
In the non-controlled environment, the greatest percentages of emerged seedlings at six months of storage were found in 'BRSMG 715A' L2 and 'BRS 413 RR', and the lowest percentages in 'BRS 1003 IPRO', 'BRS 284', and 'DM 6563 IPRO' (Table 3). Thus, considering that the highest isoflavone content was found in 'BRSMG 715A' L2, followed by 'BRSMG 715A' L1 and 'DM 6563 IPRO', it is not possible to relate this compound with the number of emerged seedlings, since 'DM 6563 IPRO' is in the group of cultivars that obtained the lowest values of emerged seedlings.

Correlation analysis, described in this study (Table 5) and by Teekachunhatean et al. (2013), confirms that there is no dependence between seedling emergence and isoflavone content. Furthermore, for seedling emergence, the increase in the storage period led to reduction in seedling emergence in all the cultivars; however, they exhibited different rates of decline (Figure 2).

The results of germination, first germination count, and seedling emergence in sand show that the cultivars responded in a similar way to periods in cold and dry storage (Figure 1), in which there is control of temperature and $\mathrm{RH}$. Nevertheless, when the seeds were stored in a non-controlled environment, different responses were detected from the cultivars (Figure 2). This confirms that the storage potential of soybean seeds is also directly related to the genetic characteristics of the cultivar, as reported by Rosa et al. (2017).

In relation to the tetrazolium test, the seeds of 'BRSMG 715A' L1 and L2, 'BRS 413 RR' and 'BMX Valente RR' had greater viability at the time prior to storage. However, it is important to highlight that the variation among the values of viability of the cultivars was from $90 \%$ to $96 \%$; thus, all had high physiological quality (Tables 3 and 4 ). At six months, the seeds of 'BRSMG 715A' (L1 and L2) and 'BRS 413 RR' in cold and dry storage showed the best results (Table 4). As the

Table 4. Viability, vigor, weathering damage and stink bug damage (classes 6-8), evaluated by the tetrazolium test, of seeds of soybean cultivars during the storage period (SP) under cold and dry storage conditions.

\begin{tabular}{|c|c|c|c|c|c|c|c|c|}
\hline \multirow{3}{*}{ Cultivar } & \multicolumn{4}{|c|}{ TZ Viability (\%) } & \multicolumn{4}{|c|}{ TZ Vigor (\%) } \\
\hline & \multicolumn{4}{|c|}{ SP (months) } & \multicolumn{4}{|c|}{ SP (months) } \\
\hline & 0 & 2 & 4 & 6 & 0 & 2 & 4 & 6 \\
\hline BRSMG 715A L1 & $96 a$ & $94 \mathrm{a}$ & $94 a$ & $92 \mathrm{a}$ & $90 \mathrm{a}$ & $88 a$ & $87 \mathrm{a}$ & $83 a$ \\
\hline BRSMG 715A L2 & 95 a & $94 \mathrm{a}$ & $95 a$ & 95 a & $88 a$ & $89 a$ & $85 a$ & $84 \mathrm{a}$ \\
\hline BRS 1001 IPRO & $90 \mathrm{~b}$ & $89 \mathrm{~b}$ & $88 \mathrm{~b}$ & $89 \mathrm{~b}$ & $84 b$ & $82 \mathrm{~b}$ & $81 \mathrm{~b}$ & $80 a$ \\
\hline BRS 1003 IPRO & $92 b$ & $89 \mathrm{~b}$ & $89 \mathrm{~b}$ & $89 \mathrm{~b}$ & $86 b$ & $81 \mathrm{~b}$ & $81 b$ & $80 \mathrm{a}$ \\
\hline BRS 413 RR & $94 \mathrm{a}$ & $93 \mathrm{a}$ & $93 a$ & $92 \mathrm{a}$ & $91 \mathrm{a}$ & $89 a$ & $88 \mathrm{a}$ & $83 a$ \\
\hline BRS 284 & $90 \mathrm{~b}$ & $88 \mathrm{~b}$ & $86 b$ & $86 c$ & $80 \mathrm{~b}$ & $79 \mathrm{~b}$ & $77 c$ & $76 b$ \\
\hline BMX Valente RR & $94 \mathrm{a}$ & $93 a$ & $86 b$ & $86 c$ & $90 \mathrm{a}$ & $89 a$ & $76 c$ & $76 b$ \\
\hline DM 6563 IPRO & $91 b$ & $86 b$ & $85 b$ & $85 c$ & $85 b$ & $78 \mathrm{~b}$ & $72 c$ & $72 b$ \\
\hline \multirow{2}{*}{ Cultivar } & \multicolumn{4}{|c|}{ TZ Weathering 6-8 (\%) } & \multicolumn{4}{|c|}{ TZ Stink bug 6-8 (\%) } \\
\hline & 0 & 2 & 4 & 6 & 0 & 2 & 4 & 6 \\
\hline BRSMG 715A L1 & $0 \mathrm{a}$ & $1 \mathrm{a}$ & $0 \mathrm{a}$ & $0 \mathrm{a}$ & $1 \mathrm{~b}$ & $0 \mathrm{a}$ & $1 \mathrm{~b}$ & $0 \mathrm{a}$ \\
\hline BRSMG 715A L2 & $0 \mathrm{a}$ & $1 \mathrm{a}$ & $0 \mathrm{a}$ & $0 \mathrm{a}$ & $3 c$ & $2 b$ & $2 b$ & $0 \mathrm{a}$ \\
\hline BRS 1001 IPRO & $1 \mathrm{a}$ & $1 \mathrm{a}$ & $2 b$ & $1 \mathrm{a}$ & $0 \mathrm{a}$ & $0 \mathrm{a}$ & $0 \mathrm{a}$ & $0 \mathrm{a}$ \\
\hline BRS 1003 IPRO & $4 \mathrm{~b}$ & $6 \mathrm{~b}$ & $3 b$ & $4 b$ & $0 \mathrm{a}$ & $1 \mathrm{~b}$ & $3 c$ & $0 \mathrm{a}$ \\
\hline BRS 413 RR & $1 \mathrm{a}$ & $1 \mathrm{a}$ & $0 \mathrm{a}$ & $1 \mathrm{a}$ & $2 b$ & $1 \mathrm{~b}$ & $0 \mathrm{a}$ & $0 \mathrm{a}$ \\
\hline BRS 284 & $1 \mathrm{a}$ & $6 \mathrm{~b}$ & $2 \mathrm{~b}$ & $5 b$ & $6 \mathrm{~d}$ & $2 b$ & $5 d$ & $2 b$ \\
\hline BMX Valente RR & $0 \mathrm{a}$ & $1 \mathrm{a}$ & $3 b$ & $3 b$ & $0 \mathrm{a}$ & $0 \mathrm{a}$ & $0 \mathrm{a}$ & $0 \mathrm{a}$ \\
\hline DM 6563 IPRO & $0 \mathrm{a}$ & $2 a$ & $2 \mathrm{~b}$ & $2 a$ & $1 \mathrm{~b}$ & $1 \mathrm{~b}$ & $0 \mathrm{a}$ & $0 \mathrm{a}$ \\
\hline
\end{tabular}

Mean values followed by the same letter in the column do not differ from each other by the Scott-Knott test at $5 \%$ probability. 
storage period increased, there was reduction in the viability of the seeds in 'BRSMG 715A' L1, 'BRS 284', 'BMX Valente $R R^{\prime}$, and 'DM 6563 IPRO', whereas the other cultivars did not show significant reduction (Figure 3).

Under non-controlled environmental conditions, different responses were found for some cultivars regarding viability, especially for the cultivar with black seed coat and greater lignin content ('BRSMG 715A' L1 and L2), which from the fourth month of storage on, already proved to be superior to the others (Table 3). In relation to the effect of the storage period, linear reductions were found in viability for all the cultivars; however, lower rates of decrease were found in 'BRSMG 715A' L1 and L2 (Figure 2).

For vigor evaluated by the tetrazolium test, the cultivars also responded differently - at six months of cold and dry storage, 'BRSMG 715A' (L1 and L2), 'BRS 1001 IPRO', 'BRS 1003 IPRO', and 'BRS 413 RR' (Table 4), as well as 'BRSMG 715A' (L1 and L2) under non-controlled conditions (Table 3), had greater vigor than the others. Similar results regarding the response of cultivars to the storage environments were also found in other variables, such as viability.

Therefore, in a more favorable storage environment (cold and dry storage), cultivars with yellow seed coat and with lower values of lignin and isoflavone in the seeds also had good performance during the storage period. However, in storage without control of temperature and $\mathrm{RH}$, only the cultivar with black seed coat and higher lignin content had a positive response regarding conservation of physiological potential.
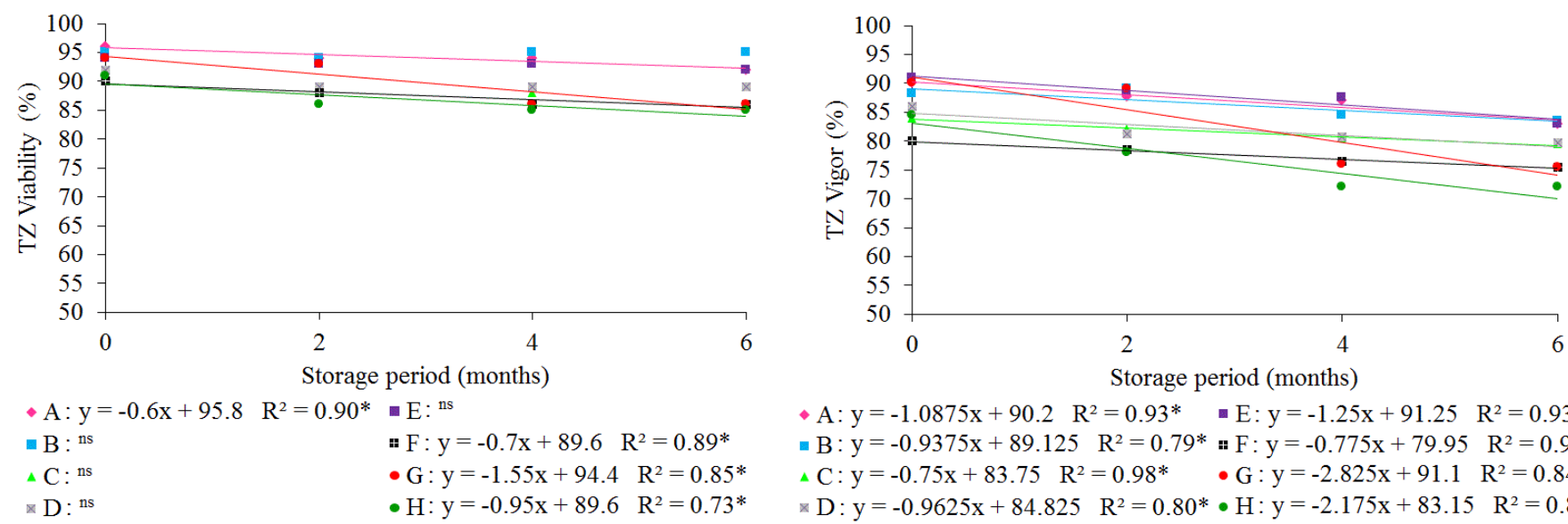

- $\mathrm{A}: \mathrm{y}=-1.0875 \mathrm{x}+90.2 \quad \mathrm{R}^{2}=0.93 * \quad \because \mathrm{E}: \mathrm{y}=-1.25 \mathrm{x}+91.25 \quad \mathrm{R}^{2}=0.93 *$

$\mathrm{B}: \mathrm{y}=-0.9375 \mathrm{x}+89.125 \mathrm{R}^{2}=0.79 * * \mathrm{~F}: \mathrm{y}=-0.775 \mathrm{x}+79.95 \mathrm{R}^{2}=0.99 *$

$\Delta \mathrm{C}: \mathrm{y}=-0.75 \mathrm{x}+83.75 \mathrm{R}^{2}=0.98 * \quad \cdot \mathrm{G}: \mathrm{y}=-2.825 \mathrm{x}+91.1 \mathrm{R}^{2}=0.84 *$

× D : $y=-0.9625 x+84.825 R^{2}=0.80 * \bullet H: y=-2.175 x+83.15 \quad R^{2}=0.89 *$
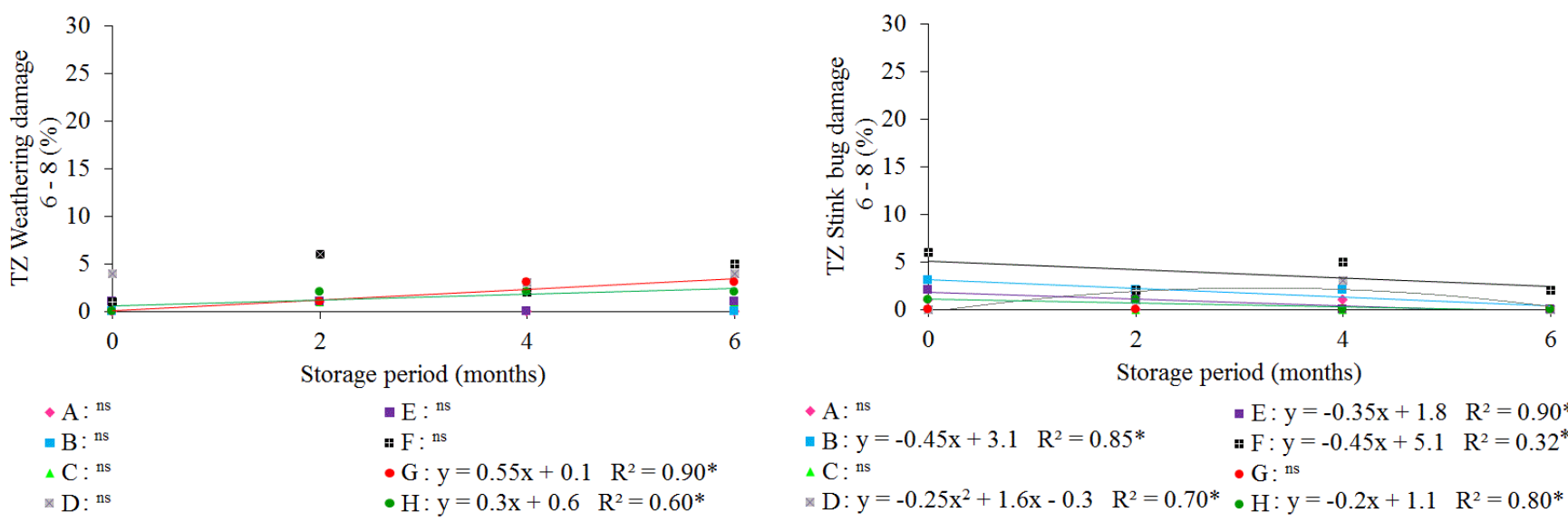
- A: ns
B: $y=-0.45 x+3.1 \quad R^{2}=0.85^{*}$
$\mathrm{C}: \mathrm{ns}$
- $\mathrm{E}: \mathrm{y}=-0.35 \mathrm{x}+1.8 \mathrm{R}^{2}=0.90^{*}$
* $\mathrm{F}: \mathrm{y}=-0.45 \mathrm{x}+5.1 \quad \mathrm{R}^{2}=0.32^{*}$
- $\mathrm{G}: \mathrm{ns}$
$\mathrm{D}: \mathrm{y}=-0.25 \mathrm{x}^{2}+1.6 \mathrm{x}-0.3 \quad \mathrm{R}^{2}=0.70 * \bullet \mathrm{H}: \mathrm{y}=-0.2 \mathrm{x}+1.1 \mathrm{R}^{2}=0.80 *$

ns and *: non-significant and significant regression, respectively, at $5 \%$ probability;

Cultivars: $A=$ BRSMG 715A L1; B = BRSMG 715A L2; C = BRS 1001 IPRO; D = BRS 1003 IPRO; $E=$ BRS 413 RR; F = BRS 284; G = BMX Valente RR; $\mathrm{H}=\mathrm{DM} 6563$ IPRO.

Figure 3. Viability, vigor, weathering damage and stink bug damage (classes 6-8), evaluated by the tetrazolium test, of soybean cultivars during the storage period under cold and dry storage conditions. 
This response is a result of lignin having a hydrophobic nature and acting directly in the permeability of the seed coat (Zhao and Dixon, 2011). Seeds with high lignin content have less seed coat permeability, which may provide greater seed tolerance to environmental oscillations, explaining the results found.

Regarding the effect of the storage period, linear reductions were found in seed vigor in the two environments (Figures 2 and 3). Nevertheless, sharper reductions were found in the non-controlled environment, with rates of decrease ranging from 0.74 to 4.03 percentage points per month (Figure 2). This reduction in seed quality as the storage period lengthens is related to the natural deterioration process, which is accelerated in environments unfavorable to maintenance of seed quality.

In this context, the better performance of the seeds in cold and dry storage is likely due to this environment having a microclimate favorable to conservation of the initial quality of the seeds. Because of the hygroscopic character of seeds, a non-controlled environment exposes them to adverse conditions, such as oscillations of temperature and $\mathrm{RH}$, which are considered the factors that most affect seed deterioration.

In the present study in cold and dry storage, constant values of temperature and $\mathrm{RH}$ were observed, with a mean of $11{ }^{\circ} \mathrm{C}$ and $54 \% \mathrm{RH}$. In the non-controlled environment, the mean values were $25^{\circ} \mathrm{C}$ and $71 \% \mathrm{RH}$, though with oscillations throughout the storage period, with temperatures ranging from $19.2{ }^{\circ} \mathrm{C}$ to $30{ }^{\circ} \mathrm{C}$ and $\mathrm{RH}$ from $52 \%$ to $84 \%$ (Figure 4). These circumstances certainly altered the metabolism of the seeds, especially of those with a yellow seed coat and lower values of lignin, and contributed to reduce the storage potential of the seeds stored in that environment. It should be noted that in Brazil, most commercial seeds are stored in conventional warehouses (in a non-controlled environment).

Just as observed in the viability data, the greatest rate of decline in vigor throughout the period of cold and dry storage was in 'BMX Valente RR', with reduction of 1.55 and 2.82 percentage points in the viability and vigor values, respectively, for each month of storage (Figure 3). It should be highlighted that 'BMX Valente RR' has the lowest lignin and isoflavone content (Table 1), which may be associated with the lower performance found in this cultivar.

In the non-controlled environment, 'BRS 1003 IPRO', 'BMX Valente RR', and 'DM 6563 IPRO' had the highest rates of decline, with reductions in viability of $2.10,2.05$, and 2.13 percentage points and in vigor of $4.03,3.65$, and 3.20 percentage points per month of storage, respectively (Figure 2). These results show and sustain the definitions regarding the physiological manifestations that occur during seed deterioration - as seeds deteriorate, there is first a reduction in vigor and then in viability (Shaban, 2013).

For mechanical damage (classes 6-8), determined in the tetrazolium test, an isolated effect of cultivar and storage periods was observed in both environments, in which 'BRS 1001 IPRO' and 'DM 6563 IPRO' had the highest values, considering the mean of the four storage periods (Table 2). In the two environments, there was an increase in latent
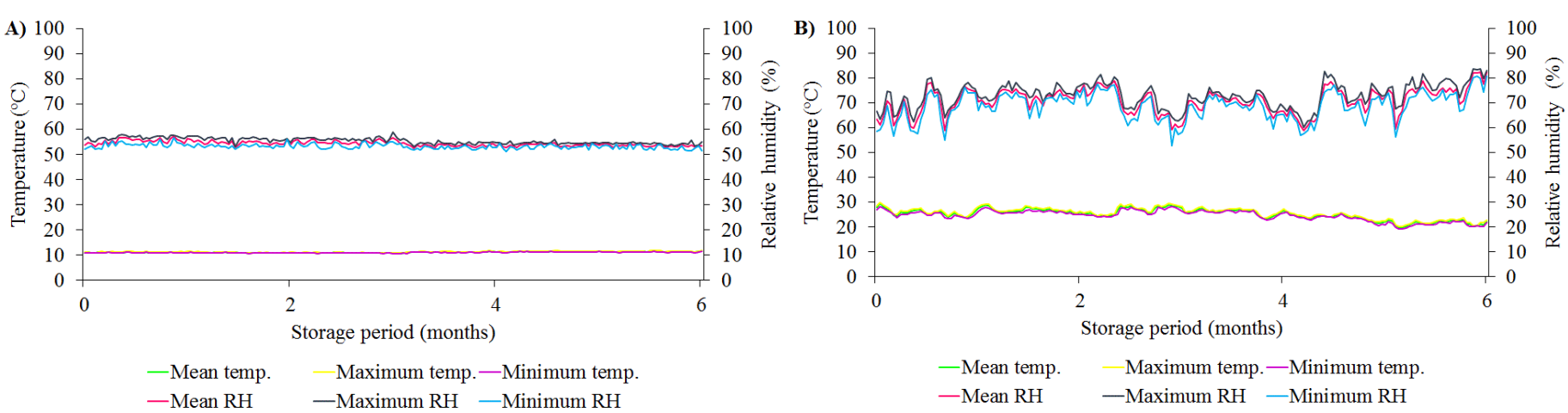

Figure 4. Maximum, mean, and minimum daily temperature $\left({ }^{\circ} \mathrm{C}\right)$ and maximum, mean, and minimum daily relative humidity (\%) during the storage period of soybean seeds in cold and dry storage (A) and in a non-controlled environment (B). 
mechanical damage, with greater rates of damage in the non-controlled environment (0.99 percentage points a month) than in cold and dry storage (0.62 percentage points a month) (Figure 1 ).

There was low incidence of weathering damage (classes 6-8), determined in the tetrazolium test, prior to storage, with the highest value (4\%) for 'BRS 1003 IPRO'. At six months of storage in the non-controlled environment, 'BRS 1003 IPRO' exhibited the highest values, with 13\% weathering damage (Table 3). This damage evolved as the cold and dry storage proceeded for 'BMX Valente RR' and 'DM 6563 IPRO' (Figure 3), and in a non-controlled environment for 'BRS 1001 IPRO', 'BRS 1003 IPRO', 'BRS 284', and 'BMX Valente RR' (Figure 2). According to Moreano et al. (2011), weathering damage is progressive, and it is the damage that most evolves during storage, corroborating the results obtained in this study.

For stink bug damage (classes 6-8), determined in the tetrazolium test, there was interaction between the factors studied for the cold and dry storage environment (Table 4; Figure 3) and an isolated effect of cultivar for the noncontrolled environment. In the latter, 'BRS 284' exhibited greater damage (5\%) than the others (Table 2).

The Pearson correlation values are presented in Table 5 for the physiological quality variables analyzed in relation to lignin content in the seed coat and isoflavone content in the seeds. Only the values that had significant correlation with at least moderate dependence $(r>0.50)$ were considered.

For lignin content in the period before storage ( 0 months), only the viability variable evaluated by the tetrazolium test showed positive correlation with this metabolite (Table 5). However, at six months, positive correlation was found for lignin content with germination, first germination count, and viability, and negative correlation with weathering damage (classes 6-8), in both storage environments. In addition, positive correlation of seedling emergence and vigor (evaluated by the tetrazolium test) was observed in the non-controlled environment.

Thus, the results presented and discussed above indicate that lignin content directly affects maintenance of germination and vigor during the storage period, especially in a non-controlled storage environment. For isoflavone content in the seeds in the period prior to storage (0 months), no significant correlation with moderate dependence was observed. At six months of storage in both environments, negative correlation was found for weathering damage (classes 6-8). Furthermore, positive correlation was found between isoflavone content and germination in the cold and dry storage environment (Table 5).

In spite of the significance of the results from correlation analysis, most correlations were weak, especially in relation to isoflavone, which is shown in the low values of the linear correlation coefficient (Table 5), indicating that there are

Table 5. Pearson correlation coefficients $(r)$ between the results of the physiological quality variables analyzed and the lignin content (LIG) and isoflavone content (ISO) in seeds of eight soybean cultivars, evaluated in the period of zero (P0) and six months (P6) of storage in cold and dry storage (CS) and in a non-controlled environment (NC).

\begin{tabular}{|c|c|c|c|c|c|c|c|c|}
\hline & GER & FGC & SE & $\begin{array}{c}\text { TZ } \\
\text { VIA }\end{array}$ & $\begin{array}{c}\text { TZ } \\
\text { VIG }\end{array}$ & $\begin{array}{c}\text { TZ MD } \\
6-8\end{array}$ & $\begin{array}{c}\text { TZ WhD } \\
6-8\end{array}$ & $\begin{array}{c}\text { TZ SBD } \\
6-8\end{array}$ \\
\hline LIG PO & $0.09^{n s}$ & $0.47 *$ & $0.26^{\mathrm{ns}}$ & $0.54 *$ & $0.08^{\text {ns }}$ & $-0.44^{*}$ & $-0.34^{\mathrm{ns}}$ & $0.14^{\mathrm{ns}}$ \\
\hline LIG P6 CS & $0.61^{*}$ & $0.63^{*}$ & $0.24^{\mathrm{ns}}$ & $0.61^{*}$ & $0.48 *$ & $-0.38^{*}$ & $-0.57^{*}$ & $-0.16^{\mathrm{ns}}$ \\
\hline LIG P6 NC & $0.60 *$ & $0.53^{*}$ & $0.52 *$ & $0.76^{*}$ & $0.68 *$ & $-0.44 *$ & $-0.57 *$ & $0.20^{\text {ns }}$ \\
\hline ISO PO & $0.21^{\mathrm{ns}}$ & $0.22^{\mathrm{ns}}$ & $0.38 *$ & $0.29^{\text {ns }}$ & $0.11^{\text {ns }}$ & $-0.24^{\text {ns }}$ & $-0.24^{\mathrm{ns}}$ & $0.12^{\text {ns }}$ \\
\hline ISO P6 CS & $0.51^{*}$ & $0.40^{*}$ & $0.17^{\mathrm{ns}}$ & $0.43^{*}$ & $0.26^{\mathrm{ns}}$ & $-0.21^{\mathrm{ns}}$ & $-0.51 *$ & $-0.19^{\text {ns }}$ \\
\hline ISO P6 NC & $0.49 *$ & $0.41 *$ & $0.28^{\text {ns }}$ & $0.48 *$ & $0.44^{*}$ & $-0.10^{\text {ns }}$ & $-0.56^{*}$ & $0.03^{\text {ns }}$ \\
\hline
\end{tabular}

ns: non-significant correlation;

*: significant correlation at $5 \%$ probability;

GER: germination; FGC: first germination count; SE: seedling emergence; TZ VIA: viability evaluated by the tetrazolium test; TZ VIG: vigor evaluated by the tetrazolium test; TZ MD 6-8: mechanical damage tetrazolium classes 6-8; TZ WhD 6-8: weathering damage tetrazolium classes 6-8; TZ SBD 6-8: stink bug damage tetrazolium classes 6-8. 
other factors that affect quality maintenance in seeds. Consequently, lignin content showed greater significance than isoflavone content regarding conservation of seed quality throughout storage.

The above considerations indicate that the metabolites originating from the phenylpropanoid pathway, especially lignin content, contribute to maintenance of seed quality during storage, especially when the seeds are exposed to unfavorable environmental conditions. In addition, different levels of tolerance to storage were seen within the group of cultivars with yellow seed coat; under cold and dry storage conditions, some of these cultivars had performance similar to those with a black seed coat, indicating that other compounds may be present in the seeds related to storage potential.

\section{CONCLUSIONS}

The physiological quality of seeds declines during the storage period, with higher rates of decline in the noncontrolled environment.

The cultivars have different responses regarding conservation of physiological potential during the storage period. The metabolites of the phenylpropanoid pathway studied here, especially lignin, affect seed storage potential.

Cultivars with higher lignin content have greater storage potential, especially when in a non-controlled environment.

\section{REFERENCES}

ÁVILA, M.R.; BRACCINI, A.L.; SOUZA, C.G.M.; MANDARINO, J.M.G.; BAZO, G.L.; CABRAL, Y.C.F. Physiological quality, content and activity of antioxidants in soybean seeds artificially aged. Revista Brasileira de Sementes, v.34, n.3, p.387-407, 2012. https://www. scielo.br/pdf/rbs/v34n3/06.pdf

BAHRY, C.A.; ACUNHA, T.S.; FERNANDO, J.A.; CHAVES, F.C.; NARDINHO, M.; ZIMMER, P.D. Chemical composition and structural characterization of contrasting colors of soybean seed coats. Semina: Ciências Agrárias, v.36, n.3, p.1913-1926, 2015. http://www. uel.br/revistas/uel/index.php/semagrarias/article/view/17920

BAHRY, C.A.; PERBONI, A.T.; NARDINO, M.; ZIMMER, P.D. Physiological quality and imbibitions of soybean seeds with contrasting coats. Revista Ciência Agronômica, v.48, n.1, p.125-133, 2017. https://www.scielo.br/pdf/rca/v48n1/1806-6690-rca-48-01-0125.pdf

BELLALOUI, N.; SMITH, J.R.; MENGISTU, A. Seed nutrition and quality, seed coat boron and lignin are influenced by delayed harvest in exotically-derived soybean breeding lines under high heat. Frontiers in Plant Science, v.8, n.1563, p.1-16, 2017. https://www. frontiersin.org/articles/10.3389/fpls.2017.01563/full

BERHOW, M.A. Modern analytical techniques for flavonoid determination. In: BUSLIG, B.S.; MANTHEY, J.A. (Eds). Flavonoids in cell function. New York: Kluwer Academic, 2002. p.61-76.

BRASIL. Ministério da Agricultura, Pecuária e Abastecimento. Instrução normativa $n^{\circ} 45$, de 17 de setembro de 2013. Anexo XXIII - Padrões para produção e comercialização de sementes de soja. Available at: http://www.agricultura.gov.br/assuntos/insumosagropecuarios/insumos-agricolas/sementes-e-mudas/publicacoes-sementes-e-mudas/INN45de17desetembrode2013.pdf Accessed on: April 22, 2021.

BRASIL. Ministério da Agricultura, Pecuária e Abastecimento. Regras para análise de sementes. Ministério da Agricultura, Pecuária e Abastecimento. Secretaria de Defesa Agropecuária. Brasília: MAPA/ACS, 2009. 399p. http:// https://www.gov.br/agricultura/ptbr/assuntos/insumos-agropecuarios/arquivos-publicacoes-insumos/2946_regras_analise_sementes.pdf

CAPELETI, I.; BONINI, E.A.; FERRARESE, M.L.L.; TEIXEIRA, A.C.N.; KRZYZANOWSKI, F.C.; FERRARESE-FILHO, O. Lignin content and peroxidase activity in soybean seed coat susceptible and resistant to mechanical damage. Acta Physiologiae Plantarum, v.27, n.1, p.103-108, 2005. https://link.springer.com/article/10.1007/s11738-005-0042-2

CARDOSO, R.B.; BINOTI, F.F.S.; CARDOSO, E.D. Potencial fisiológico de sementes de crambe em função das embalagens e armazenamento. Pesquisa Agropecuária Tropical, v.42, n.3, p.272-278, 2012. https://www.scielo.br/pdf/pat/v42n3/a04v42n3.pdf

CARRÃO-PANIZZI, M.C.; FAVONI, S.P.G.; KIKUCHI, A. Extraction time for isoflavone determination. Brazilian Archives of Biology and Technology, v.45, n.4, p.515-518, 2002. https://www.scielo.br/pdf/babt/v45n4/15251.pdf 
CARVALHO, E.R.; MAVAIEIE, D.P.R.; OLIVEIRA, J.A.; CARVALHO, M.V.; VIEIRA, A.R. Alterações isoenzimáticas em sementes de cultivares de soja em diferentes condições de armazenamento. Pesquisa Agropecuária Brasileira, v.49, n.12, p.967-976, 2014. https://www.scielo.br/pdf/pab/v49n12/0100-204X-pab-49-12-00967.pdf

CHOI, Y.M.; YOON, H.; LEE, S.; KO, H.C.; SHIN, M.J.; LEE, M.C.; HUR, O.S.; RO, N.Y.; DESTA, K.T. Isoflavones, anthocyanins, phenolic content, and antioxidant activities of black soybeans (Glycine max (L.) Merrill) as affected by seed weight. Scientific Reports, v.10, n.19960, p.1-13, 2020. https://www.nature.com/articles/s41598-020-76985-4.pdf

FERREIRA, D.F. Sisvar: a computer statistical analysis system. Ciência e Agrotecnologia, v.35, n.6, p.1039-1042, 2011. https://www. scielo.br/pdf/cagro/v35n6/a01v35n6.pdf

FRANÇA-NETO, J.B.; KRZYZANOWSKI, F.C.; HENNING, A.A.; PÁDUA, G.P.; LORINI, I.; HENNING, F.A. Tecnologia da produção de semente de soja de alta qualidade. Londrina: Embrapa Soja, 2016. 82p.

FRANÇA-NETO, J.B.; KRYZANOWSKI, F.C. Metodologia do teste de tetrazólio em sementes de soja. Londrina: Embrapa Soja, 2018. 108p.

FRANÇA-NETO, J.B.; KRZYZANOWSKI, F.C.; HENNING, A.A.; HENNING, F.A.; LORINI, I. Mapeamento da qualidade da semente de soja produzida no Brasil. Seed News, edição XXIV, n.5, p.20-25, 2020. https://seednews.com.br/artigos/3361-mapeamento-daqualidade-da-semente-de-soja-produzida-no-brasil-edicao-setembro-2020

HUTH, C.; MERTZ-HENNING, L.M.; LOPES, S.J.; TABALDI, L.A.; ROSSATO, L.V.; KRZYZANOWSKI, F.C.; HENNING, F.A. Susceptibility to weathering damage and oxidative stress on soybean seeds with different lignin contents in the seed coat. Journal of Seed Science, v.38, n.4, p.296-304, 2016. https://www.scielo.br/pdf/jss/v38n4/2317-1545-jss-38-04-00296.pdf

KRZYZANOWSKI, F.C.; FRANÇA-NETO, J.B. Looking at lignin. Seed Testing International, n.155, p.9-11, 2018. https://ainfo.cnptia. embrapa.br/digital/bitstream/item/176208/1/Lignin.pdf

LIU, J.; OSBOURN, A.; MA, P. MYB transcription factors as regulators of phenylpropanoid metabolism in plants. Molecular Plant, v.8, p.689-708, 2015. https://www.cell.com/action/showPdf?pii=S1674-2052\%2815\%2900180-X

MARWANTO, M.; MARLINDA, M.D. The relationship between seed coat lignin content and seed quality of soybeans during storage. Jurnal IImu Pertanian Indonesia, v.5, n.1, p.12-17, 2003. http://repository.unib.ac.id/210/1/12.pdf

MERTZ, L.M.; HENNING, F.A.; CRUZ, H.L.; MENEGHELLO, G.E.; FERRARI, C.S.; ZIMMER, P.D. Diferenças estruturais entre tegumentos de sementes de soja com permeabilidade contrastante. Revista Brasileira de Sementes, v.31, n.1, p.23-29, 2009. https://www. scielo.br/pdf/rbs/v31n1/a03v31n1.pdf

MOREANO, T.B.; BRACCINI, A.L.; SCAPIM, C.A.; KRZYZANOWSKI, F.C.; FRANÇA-NETO, J.B.; MARQUES, O.J. Changes in the effects of weathering and mechanical damage on soybean seed during storage. Seed Science and Technology, v.39, n.3, p.604-611, 2011. https://doi.org/10.15258/sst.2011.39.3.07

MOREIRA-VILAR, F.C.; SIQUEIRA-SOARES, R.C.; FINGER-TEIXEIRA, A.; OLIVEIRA, D.M.; FERRO, A.P.; ROCHA, G.J.; FERRARESE, M.L.L.; SANTOS, W.D.; FERRARESE-FILHO, O. The acetyl bromide method is faster, simpler and presents best recovery of lignin in different herbaceous tissues than Klason and thioglycolic acid methods. Plos One, v.9, n.10, p.1-7, 2014. https://journals.plos.org/plosone/ article?id=10.1371/journal.pone. 0110000

R DEVELOPMENT CORE TEAM. R: a language and environment for statistical computing. Vienna, Austria: $R$ Foundation for Statistical Computing, 2018. Available at: https://www.r-project.org Accessed on: June 20, 2018.

ROSA, D.P.; NOBRE, D.A.C.; OLIVEIRA, D.S.; SILVA, F.C.S.; BEZERRA, A.R.G.; SILVA, A. F.; SEDIYAMA, T. Genetic diversity in soybean seed quality under different storage conditions. Semina: Ciências Agrárias, v.38, n.1, p.57-72, 2017. https://www.redalyc.org/ pdf/4457/445749994005.pdf

SCHONS, A.; SILVA, C.M.; PAVAN, B.E.; SILVA, A.V.; MIELEZRSKI, F. Respostas do genótipo, tratamento de sementes e condições de armazenamento no potencial fisiológico de sementes de soja. Revista de Ciências Agrárias, v.41, n.1, p.109-121, 2018. https:// revistas.rcaap.pt/rca/article/view/16630/13546

SHABAN, M. Review on physiological aspects of seed deterioration. International Journal of Agriculture and Crop Sciences, v.6, n.11, p. 627-631, 2013. https://www.cabdirect.org/cabdirect/abstract/20133372482

TEEKACHUNHATEAN, S.; HANPRASERTPONG, N.; TEEKACHUNHATEAN, T. Factors affecting isoflavone content in soybean seeds grown in Thailand. International Journal of Agronomy, v2013, p.1-12, 2013. https://www.hindawi.com/journals/ija/2013/163573/ 
VIDIGAL, D.S.; WILLEMS, L.; ARKEL, J.V.; DEKKERS, B.J.W.; HILHORST, H.W.M.; BENTSINK, L. Galactinol as marker for seed longevity. Plant Science, v.246, p.112-118, 2016. https://www.sciencedirect.com/science/article/abs/pii/S0168945216300279?via\%3Dihub

ZABALA, G.; VODKIN, L.O. Methylation affects transposition and splicing of a large CACTA transposon from a MYB transcription factor regulating anthocyanin synthase genes in soybean seed coats. Plos One, v.9, n.11, p.1-20, 2014. https://doi.org/10.1371/ journal.pone.0111959

ZHAO, Q.; DIXON, R.A. Transcriptional networks for lignin biosynthesis: more complex than we thought? Trends Plants Science, v.16, n.4, p.227-233, 2011. https://pubmed.ncbi.nlm.nih.gov/21227733/ use, distribution, and reproduction in any medium, provided the original work is properly cited. 